\title{
Atypical real estate objects: legal regime and control system
}

\author{
Elena Voskresenskaya ${ }^{1, *}$, Vitaly Snetkov ${ }^{1}$, Alexander Tebryaev ${ }^{1}$ and Zokhidjon Askarov ${ }^{1}$ \\ ${ }^{1}$ Peter the Great Saint Petersburg Polytechnic University, 195251, St. Petersburg, Polytechnicheskaya \\ str., 29, Russia
}

\begin{abstract}
The legal concept of immovable things raises controversy in legal practice. Determining and understanding the definition of real estate, the complexity and diversity of these objects, a growing appearance of socalled atypical properties (such as sport stadiums, roads, boreholes), analyzing legislation and judicial practice of this field - all these issues call for a deep study of this topic. There is a conflicting arbitration practice, the subject of which is the learning of the legal nature of atypical real estate (for instance, asphalt playgrounds, car parks, fences, wells). The object of the research is the learning of the legal status of atypical real estate.
\end{abstract}

\section{Introduction}

During the research, the authors applied the methods of theoretical analysis and synthesis of various sources, the system-structural method, the method of generalization of sources and other methods.

The nature of real estate objects was considered in the works of R.S.Bevzenko [1], A.E.Zakharova [2], D.Bazarkina [3], A.Ya.Rizhenkova [4], O.K.Tikk [5], D.E.Potyarkina [6], D.S.Nekrestyanova [7], S.P.Grishaeva [8] and other authors [10-19,21,23].

Today in our country one can see steadily increasing disputes arising in the area of real estate turnover. S.P.Grishayev nots: "Many of the problems that arise in the arbitration practice of the sphere of the economic turnover of real estate, ultimately, come back to the concept and features of this phenomenon"[8]. Actually, the definition of the real estate, contained in Article 130 of the Civil Code of the Russian Federation [9] is stated in such way, that the decision of the content categories of real estate takes on not only a theoretical, but also a practical significance.

Thus, the assignment of an object to the category of movable or immovable property shall entail the appropriate legal consequences, and in practice this fact affects the resolution of the dispute.

At the present time, the legal definition of property enshrined in Paragraph 1, Article 130 of the Civil Code of Russian Federation: "The immovables (the immovable property, realty) should comprise land plots, land plots with mineral deposits and everything else, what is closely connected with the land, i.e., objects that cannot be shifted without causing an enormous damage to their purpose, including the buildings and all kind of structures,

\footnotetext{
${ }^{*}$ Corresponding author: elenvoskr@mail.ru
} 
objects of incomplete construction. The air-borne and sea-going vessels, the inland navigation ships and the space objects shall also be referred to immovables. The law may also refer to the immovables other certain types of property". According to the paragraph 2 of Article 130 Civil Code of the Russian Federation "The things, which have not been referred to immovables, including money and securities, shall be regarded as movables" [9].

First of all, it is worth mentioning that the definition of "property", "immovable things", "real estate" are identified. But in legal science the consensus on the position of the legislator has not developed. Thus, some authors agree with the synonymous of this definition, indicating that it is "the reception of legal technique, which is used by the legislator to avoid monotony in the text of the law"[10]. Indeed p.1 Article 131 of the Civil Code says about the state registration of rights to immovable property, p.2 - on the registration or recognition of certain types of real estate, p.3 - the authority responsible for state registration of rights to real estate and transactions with it. However, some scientists base on differences between the concepts of "immovable" and "real estate", which seems more reasonable.

\section{Experimental section}

The definition of "immovable" category is quite natural, because, according to most civilists, only a thing can be the subject of property rights. Therefore, Professor Sukhanov E.A. claims: "The objects of property rights in the Russian law cannot act as property rights - the right to claim, right of use, etc." [11].

Confirmation of this statement is contained in Article 132 of the Civil Code, which defines the company as a property complex recognized as real estate, which consists of various categories of property intended for activities including not only immovable things, but also equipment, inventory, raw materials, products, rights, claims, debts and exclusive rights. From this follows the conclusion that the definition of property given in the Article 130 of the Civil Code, more in line with the concept of "immovable things", and in Article 132 of the Civil Code - the concept of "realty" [12].

As for the term "real estate", it is preferable to use it as a kind of generalizing categories when it comes to objects of civil rights, which are subject to a special legal regime of immovable property, for example, in the norms of obligatory state registration. Thus, the doctrine has no clear understanding on the studied issue.

The most common point of view is that necessary to exclude from the Article 130 of the Civil Code references to "real estate (immovable property)" and "property", and to focus on the category of "immovable things", thus emphasizing, that "the object of the right to real estate are only objects of material form" [13].

According to the remark of P.Vinogradov, Article 130 of the Civil Code contains a symbiosis of approaches to the definition of immovable property: the fixation feature a strong link with the land, which implies that it cannot move without disproportionate damage to its purpose at the same time, this provision contains a list of immovables, which is not closed [14].

Now let us turn to the real estate features. There is a variety of opinions on the criteria of real estate in the legal literature. At the present time, the criteria of the strong link with the land can cause considerable difficulties. It is explained by the fact that modern technologies make it possible to move from place to place any building or structure without causing serious damage, while keeping its integrity and assigning ("but as real estate they may be qualified only if an inextricable physical connection to the earth occurs again "[8]). For example, the wooden houses $(\log )$ in rural areas are fairly often transferred disassembled from one place to another. 
It is obtained that the physical relatedness of the object to the land is understood as a condition of use of immovable property for other purposes. Characterizing feature of a strong link with the land in her own work, L.Naumova identifies the following elements: "the existence of the concrete foundation, its characteristics, the method of attachment of the object to the concrete foundation and the material from which the object is made". [15]

Professor O.N. Sadikov makes categorical conclusion that the defining feature of classification of the object to real estate is its strong link with the land. Object will not be the object of real estate if a strong link with the land is absent [16]. However, in the legal literature there are doubts about the absoluteness of this conclusion.

So, Emelkina I.A. points out that "many of the objects that do not have a strong link with the land belong to the real estate. For example, an apartment on the fifth floor or office will be treated as the real estate is not because of strong link with the land, but due to the direct reference in the law (Article 1 of the Federal Law "On State Registration of Rights to Real Estate and Transactions Therewith")" [17].

Indeed, the link with the land can also be physical, but indirectly (through the water surface, through other real estate, buildings and structures built on water, residential and non-residential premises). Therefore, it follows that the presence of the concrete foundation does not indicate the construction of real estate - it is just one of the characteristics of the property, that can only be used in conjunction with other features. Jurists have suggested to enter a legal criterion according to which an object links to the land, assuming only the recognition of real estate objects, the land under which belongs to the person by the right of ownership. Accordingly, there is the conclusion that buildings situated not on their own land will receive the status of movable property.

Criticizing this position, L. Shchennikova points out that "in modern Russian conditions, when many owners of buildings and structures do not possess and use the land by right of ownership, most of the objects will no longer be real estate" [18].

A number of other scientists, speaking about the legal relationship of the object with the land, refers to the rules about the unauthorized construction - 222 of the Civil Code. Authors deny the existence as real estate illegally built residential building, existing buildings, structures, etc. until the emergence of property rights to such objects, i.e. before the state registration of these objects.

However, V.A. Alekseev took the opposite position: "circumstance that there is no right of ownership, should not lead to the finding that they are not considered as real estate but considered as a movable property" [19]. It seems correct to agree with this point of view, based on the logic of the relevant legislation. Civil Code, giving in art. 222 the definition of unauthorized construction, indicates that it is - real estate, created on land not designated for that purpose in accordance with the law and other regulations or established without obtaining the necessary permits or with substantial violation of town planning or building norms and rules [9].

Thus, it is true that the illegality of the construction is the criterion for inclusion real estate to the unauthorized construction, rather than addressing the issue of assigning an object to a real estate.

The next legal criterion is the inability to move an object without disproportionate damage to its purpose. In legal practice there are cases of the court decisions based on this feature: the court did not recognize the disputed transformer substation of immovable property, because it came to the conclusion about the possibility of moving it without disproportionate damage to its purpose. The transformer station is a metal cabinet with the equipment installed on a foundation of steel pipe ".

However, disproportionate damage criterion also raises a number of questions. The definition of "disproportionate" has evaluative nature, and the lack of this criterion means that neither the legislator nor the practice do not answer the question, how it should 
decrease the value of the property $(1 / 2,1 / 3,1 / 4$, etc.). Besides, it is not clear which cost of the object should be the basis. L. Naumov offers cost of the object based on the evaluation and compared with the same object after it was moved, as well as with the assessment of the costs to move [15]. It is also not defined clearly which cost should be taken into account - the market, the balance, the cost of the evaluation of technical inventory authorities. All of them are calculated by different methods. It seems that the market valuation should be used as the most fully reflects the value of the property.

At the same time, some practitioners suggest to exclude feature inability to move without disproportionate harm to the purpose [7]. This conclusion related to the fact that any movement shall entail the termination of the existence of the real estate object. The fact of movement suggests that at the beginning of moving the object ceased its existence, and in all cases, it will be a new object. After considering the criteria in Article 130 of the Civil Code, one can conclude that in practice there are several questions: how and when to recognize them as sufficient to recognize the immovable object; when these criteria will cease to be subjective and dependent on the will of the registrar or the judge in the proceedings.

Out of this situation D. Bazarkin offers: " all objects of the material world, recorded by the State Real Estate Cadastre will automatically recognize as real estate. At the same time the criteria of "a strong link with the land" and "immovability" of the object of material world will move it from objective category to subjective one and it will be criteria for the registration object in the State Real Estate Cadastre. It is necessary to introduce a new criterion "considered at the State Real Estate Cadastre, which will be the basis for the state registration of rights to property" [3].

The assignment of an object to the capital is a matter, which is derived by the analysis of normative sources and materials of judicial practice. Therefore, Article 1 of the Town Planning Code of the Russian Federation defines the following: the object of capital construction is building, structure, facility, facilities, construction of which has not been completed (hereinafter - construction in progress), except for temporary buildings, stalls, sheds and other similar structures [20].

D. Nekrestyanov emphasizes features of spatial individuality, which requires to bind on real estate characterizing the presence of the aggregate of its features for change to all or some of them entail the termination of the object and the emergence of the new. "Location, area, cadastre number - this is a minimum set of features that is given to each object - is unique of its existence" [7]. It seems that the author bases his position based on the provisions of the Federal Law "On State Real Estate Cadastre", which within the meaning of paragraph 3 Article 1 of follows the conclusion that the object must have characteristics that enable to define real estate as individual-specific things (the unique characteristics of the object real estate).

A.M. Erdelevsky indicates that certain types of real estate may only be used in accordance with their intended purpose, for example, land, premises and other [21].

\section{Results section}

The learning of judicial acts solved the issue of whether the specific object of real estate leads to the following conclusion: today the increasing number of cases, where unusual objects entered into circulation, was indicated as immovable property. The following things are registered as real estate: fences, asphalt playground, sports fields, parking lots, etc. There are two approaches of the determination of whether a corresponding object of real estate is or is not in the judicial practice. The first approach is that the courts have analyzed the presence of a specific object of real estate features, provided for by Article. 130 of the Civil Code: the inextricable link with the land, inability to move the objects without 
disproportionate damage to their purpose. In the second approach the courts establish whether technical inventory authorities datasheet on the subject was issued. The presence of a passport is recognized as only and sufficient proof that an object is immovable property. As an example, we can give the qualification as a real estate of sewer networks, under which the courts understand the system of trenches, pits, and other stationary elements placed in the ground, is inextricably linked with the land, which can move without causing damage to their purpose impossible.

It turns out that the main reason for the creation of real estate sector and its introduction into civil circulation is its ability to give a set of things that special quality that these things do not possess individually. Being outside the complex, these things on their function, have been unable to satisfy the specific needs of those individuals who is able to satisfy a set of objects, which is appear the real estate complex. It should be noted that from the enterprise, a single technological complex differs in that it consists of only the things, but not the rights and duties. As of today, can be distinguish these most common technological complexes of immovable property, as the technological systems in the field of gas supply, technological systems in the field of power supply, technological systems in the field of transport. To property complex can be attributed, and a linear cable communications facilities.

Now let us consider the legal status of objects alternative to the natural. For the needs of the construction as such analogs used artificially created territory - earth mounds and alluvial areas. Generally the representation of land reclamation is "the process of applying hydromechanical method of soil on the bottom areas of the water body, which resulted in creating an artificial land plot" [5].

Today there is no unambiguous position of what is meant by the alluvial area. From one side, alluvial territories - a part of the earth's surface, from the other - a artificial object. It turns out that alluvial territories may be regarded as either a land or a building.

If we consider the alluvial territory as construction, it should be noted that such a structure has its own purpose, other than the general purpose of the land determined by permitted use land category [22]. This object will serve as an independent function, such as protecting the area from flooding. Accordingly, the alluvial area will be the object of an independent real estate. Creating alluvial territory also implies giving land plot of permanent improvements because of measures for improvement. This improvement will not be the object of real estate, because they do not have self-respect to a land plot purpose and functions, so alluvial area and the land will be integrated.

In order to avoid such ambiguity, the property and the legal status of alluvial territories at the legislative level must be secured [23].

Earth mounds cannot be recognized as objects of real estate, since they do not respond criteria of article 130 of the Civil Code: component of its soil can be moved to any other place without damage to their function.

Besides, they do not have the characteristics to personalize such property, as the soil from which the earth embankment consists, has no individual features.

Hydraulic structures should be considered as an integral part of the land (ditches, dams, etc.). Structures are strongly connected with the land and their movement without disproportionate damage to purpose is impossible. Controversial objects have no independent functionality, created exclusively to improving the quality of the land and serve only the land on which they are located, they are therefore an integral part of and in relation to Article 135 of the Civil Code must follow the fate of this land".

There is an ambiguity in the judiciary practice when it comes to fences. For the purposes of Article 226 of the Civil Code one can conclude that the fence has no independent value as an object of law. Its purpose is to designate borders and restrict the access to the ground area.

There is also no clarity in identification of such an object as draw-well. 
On the one hand, the draw-well can be described as an accessory land, subsoil. A well is a "difficult engineering construction, which is inseparably connected with the land and subsoil, and does not move in space." This conclusion is supported by the fact that drawwells require continuous operation to produce drinking water, i.e., this structure is not of a temporary nature, and this feature, combined with the above, also shows that the well has a real estate asset. It seems correct to refer a drilling well to objects of immovable property because such objects are characterized by a strong link with the land, subsoil; they are well designed for continuous operation and are intended for the extraction of groundwater.

It is impossible to refer playgrounds to the objects of real estate. Sport facilities, built on a land plot (horizontal bars, gates, benches, fencing, fitness equipment, etc.) are not real estate, since their movement does not lead to disproportionate damage to their purpose (even though they can be firmly connected with the ground).

\section{Discussion section}

For a long time there was no regulation of the legal status of parking spaces in the Russian legislation. It gave a rise to numerous disputes over attribution of parking places to the objects of real estate and the order of disposition. Numerous court cases have formed both positive and negative practices. Recently one of the most controversial legal relationship objects - parking space - officially became an object of real estate (on the $1^{\text {st }}$ of January 2017)

After recent changes in civil legislation one can say that the legislator has given due attention to this problem and followed the path of recognition of parking spaces independent object of the real estate. The parking place borders should be reflected on the floor plan and physically marked with the corresponding markings for registration of the ownership. The owners of paid parking sigh: The lessee of the place will carry the responsibility for the safety of the vehicle, not the owner of the car park, as it was before. The law introduces the concept of parking lots as individually specific part of a building or a structure, designed exclusively for the vehicle. Parking space cannot be confined or partially restricted with building or other walling.

According to the changes introduced by legislators, location of parking lots should be reflected in the floor plan of the building or structures or floors through a graphical display on its geometric shape, fully compliant with parking places boundaries. The borders of the same parking place on the floor will be possible to designate a physically different way. Such methods including the application relates to a floor surface or corresponding markup roof (paint, using all kinds of labels or other means). The main issue is to correspond to the actual borders. The long-awaited novel will resolve the issue with the legal status of parking places in buildings. The owners of parking places will be able to procedure established by law to dispose of the rights to them. Sell or rent a car place will be much easier and safer.

\section{Conclusions}

The characteristics used by legislators (strong connection to the land and disproportionate damage) now are being criticized by the majority of civilists. In literature many remarks were made, so there is no need to speak about unified position. Various authors offer different numbers of features from the classic ones (close connection with the land and inability to move without disproportionate damage) to a whole set of criteria, the use of which is considered sufficient to determine the nature of an object only in combined way. In practice, it can lead to incorrect qualification of an object that will generate the adverse 
effect on the whole civil turnover. Therefore, the required features, allowing to qualify a thing as a real estate, should be fixed in the Law. At the same time, two features of limiting and determining (strong connection to the land and disproportionate damage) are not reasonable. As many as possible features should be mentioned in order to reduce the risk of errors in determining practical things as a real estate. Today there is only one real estate object, which is recognized by everyone without exception: a ground area. Process of the real estate determination should be improved. It is necessary to consolidate the required features in the law, which will allow qualifying a thing as a real estate. According to the concept of multiplicity of types of real estate adhering the Russian law, it is necessary to classify the objects of real estate, not only to list them as it is in Article 130 of the Civil Code. The purpose of immovable things and the following qualitative differences of immovables should be the basis of the classification: strong connection to the ground, major construction of buildings and facilities intended for the permanent use.

\section{References}

1. R.S. Bevzenko. Zakon. 6 (2008)

2. A.E.Zakharova. The concept of the real estate on the Russian civil law. Statut (2002)

3. D. Bazarkin. EJ-Yurist. 15 (2012)

4. URL: http://www.new.volsu.ru (2017)

5. O.K. Tikk. Zakon. 1 (2007).

6. D.E. Potyarkin. Pravo i ekonomika. 1 (2007)

7. D.S. Nekrestyanov. Arbitrazhniye spori. 4 (2006)

8. S.P. Grishaev. The legal regime of the real estate (Consultant plus, 2007)

9. The Civil Code of the Russian Federation from 30.11.1994 №51-FZ (2016) SZ the Russian Federation. 32. 3301 (1994).

10. D. I. Ilyin. Magazine of Russian law. 8 (2005)

11. E.A. Sukhanov. Journal of civil law. 4 (2008)

12. J. A. Kaminsky. The legal issues of the real estate. 1 (2008)

13. E.M.-Tuzhilova Ordanskaya. Magazine of Russian law. 6 (2004)

14. P.Vinogradov. Real estate: the historic and the modern understanding, the Bulletin of notarial practice. 2 (2008).

15. L. Naumov. EJ-Yurist. 4 (2005).

16. H.E. Sadikov. Civil law. Textbook. (INFRA-M, 2006)

17. I.A. Emelkina. Civil law. 2 (2005).

18. L. Shchennikova. Real estate: Legal formulation and conceptual approaches (Russian justice, 11, 2003)

19. V.A. Alekseev. Real estate: the state registration and the problems of legal regulation (Wolters Kluwer, Moscow, 2007)

20. Town Planning Code of the Russian Federation of 29.12.2004 №190-FZ (2016)

21. S.P. Grishaeva, A.M. Erdelevsky, Comment to the Civil Code of the Russian Federation (itemized) ( Yurist, 2005)

22. Land Code of the Russian Federation of 25.10.2001 number 136-FZ (2016) "Collection of the legislation of the Russian Federation", 44, 4147 (2001)

23. E.V.Voskresenskaya, Modern Law. 3 (2007) 